\title{
Exogenous Melatonin, Hydrogen Sulfide and Nitric Oxide Effects on Organic Acid Content of Eruca sativa L. under Salt Stress
}

\author{
Metin Turan ${ }^{1}$, Tuba Arjumend ${ }^{2}$, Ertan Yıldırım ${ }^{3}$ Melek Ekinci $^{4}$ Betül Ince $^{5}$ \\ ${ }^{1}$ Department of Genetics and Bioengineering, \\ Yeditepe University, 34755, Istanbul, Turkey \\ ${ }^{2}$ Department of Plant Protections \\ Faculty of Agriculture, Usak University, Turkey \\ ${ }^{3}{ }^{\prime} 5$ Department of Horticulture, Faculty of Agriculture, \\ Ataturk University, 25240, Erzurum, Turkey
}

\begin{abstract}
:
Salt stress affects agricultural output by influencing numerous internal metabolisms in plants and disrupting physiological and biochemical activities such as photosynthesis, translocation, respiration, and growth stimulants. The role of exogenous melatonin, hydrogen sulfide and nitric oxide application on the organic acid contents of rocket plants under salt stress was examined in this study. Different salt doses $(0$, 150 and $250 \mathrm{mM} \mathrm{NaCl})$ and exogenous applications $(0,50$ and $100 \mu \mathrm{M})$ were made to rocket plants under the greenhouse conditions. Plants leaves and roots exhibited a decline in the organic acid contents under salinity stress. Application of the amendments, however, was found significant in mitigating the negative effect of salt stress. Melatonin and hydrogen sulfide treatments had a stronger anti-salt action in the leaves. On the other hand, nitrous oxide effect was more obvious in the roots followed by melatonin. With this, exogenous applications to the plant mitigated the harmful effects of salt stress on organic acid contents depending on the dose.
\end{abstract}

Keywords: Organic acid, rocket, salinity, nitric oxide, hydrogen sulfide, melatonin

\section{Introduction}

Salinity is one of the most important abiotic stress factors affecting yield and quality in agricultural production. Salt stress generally causes inhibition in plant growth, and in case of long-term effects, it results in plant deaths [1]. Salt stress adversely affects seed germination, morphological characteristics, plant growth, yield and components, decreases the rate of photosynthesis and respiration in the plant. Salt stress increases abscisic acid synthesis in the plant, causing closure of stomata, thus decreasing photosynthesis, and also causing oxidative stress [2]. Salinity causes a deterioration in the plant nutrient balance, usually due to the competition of $\mathrm{Na}^{+}$and $\mathrm{Cl}^{-}$with nutrients such as $\mathrm{K}^{+}, \mathrm{Ca}^{2+}$ and $\mathrm{NO}_{3}^{-}$, resulting in nutrient deficiency or imbalance. Under salt stress, low molecular weight organic solutes (linear polyols such as glycerol, mannitol or sorbitol, cyclic polyols, amino acids such as glutamate or proline, and betaines) can accumulate in plants [2]. In salt stress, qualitative and quantitative changes occur in various organic compounds such as nitrogen (N) compounds and organic acids in plants [3].

In order to alleviate or prevent the negative effects of salt stress on the morphological, physiological and biochemical properties of plants, various applications are made to the plant in exogenous forms. The reason for using these practices is that breeding studies to obtain salt-tolerant varieties take many years and require a lot of effort. These applications are made at low concentrations and even show their effects in a very short time. Nitric oxide, melatonin and hydrogen sulfide are some of the applications use exogenously to alleviate or prevent salt stress damage in plants.

Melatonin, an indoleamine commonly found in plants, is a phytohormone that acts in biotic and abiotic stresses. Salt stress causes melatonin accumulation in plants. Melatonin, in salt-stressed plant; it has effects 
such as scavenging reactive oxygen species, increasing antioxidant enzyme activity, increasing photosynthetic efficiency and metabolite content, and regulating stress-related transcription factors [4].

Nitric oxide (NO) is an uncharged, small, gaseous free radical signaling molecule. It has a wide variety of physiological roles in processes such as seed germination, maturation and senescence in plants. Nitric oxide functions as an antioxidant that prevents ROS during stress, reduces lipid peroxidation, mediates photosynthesis and stomatal conductivity, regulates programmed cell death, and thus provides tolerance to abiotic stress [5].

Hydrogen sulfide $\left(\mathrm{H}_{2} \mathrm{~S}\right)$ is a gas signaling molecule involved in processes such as seed germination, plant growth and development, and stress tolerance in plants [6].

Many researchers have been conducted on the beneficial role of these three molecules against abiotic stresses, especially salt stress, in various plants. However, there are not enough studies on their effect on rocket plants, especially in regard to organic acid metabolism. In this study, the effect of exogenous applications on the organic acid content of the rocket plants under salt stress was investigated.

\section{Materials and Methods}

An experiment was conducted in the greenhouse of the horticulture department of Ataturk University, Erzurum Turkey. Eruca sativa L. seeds were used as plant material and melatonin (ME), hydrogen sulfide (HS) and nitric oxide (NO) were applied exogenously at 3 different doses (0, 50 and $100 \mu \mathrm{M})$. Sodium chloride at 0,150 and $250 \mathrm{mM} \mathrm{NaCl}$ was used to create salt stress environment. First, seeds were sown in 1.5 L pots containing a mixture of peat: sand (2:1). After the germination, thinning was done to have 6 plants in each pot. Amendments were applied as a foliar application before sowing, and by spraying on plant leaves after seed emergence. Salt application was started at the lowest level e.g. $25 \mathrm{mM}$, in order to prevent sudden stress in plants and was gradually increased and fixed at the target dose. Soil salt level as well as the irrigation time was checked with a soil moisture meter (WET Sensor) at intervals of approximately 2 days. The study was conducted in 3 replicates with 6 plants each. After almost 30 days, plants were sampled to determine the organic acid content in the leaves and the roots.

\subsection{Organic acid determination}

Analysis was performed according to Siddiqui et al. [7]. To $1 \mathrm{~g}$ of sample, deionized water (10 $\mathrm{mL})$ was added, and the solution was homogenized with ultra turrax. The supernatants were filtered through $0.22 \mathrm{~m}$ filters after centrifugation for 50 minutes at $1,200 \mathrm{rpm}$. Supernatants were subjected to HPLC in vials using a Zorbax Eclipse-AAA $4.6250 \mathrm{~mm}, 5-\mathrm{m}$ column (Agilent $1200 \mathrm{HPLC}$ ) and measured at $220 \mathrm{~nm}$ in a UV detector. The column temperature was $25^{\circ} \mathrm{C}$ and the flow rate was $1 \mathrm{~mL} \cdot \mathrm{min}-1$. Using $25 \mathrm{mM}$ potassium phosphate ( $\mathrm{pH} 2.5)$ as the mobile phase the organic acid content was determined. Variance analysis was used to evaluate the data and the differences between the applications were determined by Duncan multiple comparison test.

\section{Results and Discussion}

In the present study, the role of exogenous melatonin (ME), hydrogen sulfide (HS) and nitric oxide (NO) on various organic acids in the leaves and roots of rocket plants under varied salt stress conditions was determined.

\subsection{Leaf organic acid content}

The organic acid content of rocket leaves is shown in the Table.1. The results of this study demonstrated that salt stress at both levels in comparison to the control led to a significant decrease in organic acid contents except citric acid. Butyric acid was affected only by the higher salt dose. In salt stressed controlled plants $(150 \mathrm{~mm} \mathrm{NaCl}, 250 \mathrm{~mm} \mathrm{NaCl})$ there was a significant decrease in the butyric acid by $16.53 \%-15.13 \%$, fumaric acid by $15.34 \%-10.13 \%$, malonic acid by $7.95 \%-22.91 \%$ and tartaric acid by $14.15 \%-4.27 \%$, respectively, compared with those grown in salt free environment.

On the other hand, exogenous application of ME, HS and NO to the plants generally increased the leaf organic acid content (Table 1). Under normal conditions, melatonin at its highest level (100 $\mu \mathrm{M} \mathrm{ME})$ resulted in a predominant increase in all observed organic acids, whereas, no significant difference was seen for the $50 \mu \mathrm{M} \mathrm{ME}$ when compared to the control. Likewise, hydrogen sulfide exhibited the similar trend as 
melatonin. Results, however, were opposite in terms of NO where lowest level (50 $\mu \mathrm{M}$ NO) had the highest effect. The highest values of butyric acid, malonic acid, succinic acid and tartaric acid were obtained at 50 $\mu \mathrm{M}$ NO, whereas citric acid, fumaric acid, lactic acid, malonic acid and propionic acid showed the highest levels at $100 \mu \mathrm{M} \mathrm{ME}$ in plant leaves without salt application.

Moreover, under salt stress, at $150 \mathrm{mM} \mathrm{NaCl}$ level, the highest contents of butyric acid, fumaric acid, lactic acid, malic acid, malonic acid, oxalic acid and tartaric acid were recorded at $100 \mu \mathrm{M} \mathrm{ME}$ application. Whereas, $100 \mu \mathrm{M} \mathrm{H} 2 \mathrm{~S}$ resulted in the highest citric acid and propionic acid values under the same conditions.

In the most severe salt application, at $250 \mathrm{mM}$ salt stress, the highest citric acid, fumaric acid and tartaric acid contents were observed with $50 \mu \mathrm{M}$ NO application, while $50 \mu \mathrm{M}$ HS application was the best in giving the highest levels of lactic acid, fumaric acid, malic acid, malonic acid and propionic acid in plant leaves. Overall, when comparing the treatments and their application rates, $100 \mu \mathrm{M} \mathrm{ME}$ was more efficient in increasing the various organic acid contents of leaves under $150 \mathrm{mM} \mathrm{NaCl}$ stress. However, $50 \mu \mathrm{M} \mathrm{HS}$ was proved more effective under $250 \mathrm{mM} \mathrm{NaCl}$ stress. This data imply that melatonin and hydrogen sulfide treatment has a more favorable impact on leaf organic acid content under salt stress conditions than nitric oxide application (Table 1).

Table 1. The effects of exogenous treatments and salinity on organic acid contents of rocket leaves $(\mathrm{ng} / \mu \mathrm{g})$

\begin{tabular}{|c|c|c|c|c|c|c|c|c|c|c|}
\hline Salt & Treatment & $\begin{array}{l}\text { Butyric } \\
\text { acid }\end{array}$ & $\begin{array}{l}\text { Citric } \\
\text { acid }\end{array}$ & $\begin{array}{l}\text { Fumaric } \\
\text { acid }\end{array}$ & $\begin{array}{l}\text { Lactic } \\
\text { acid }\end{array}$ & $\begin{array}{l}\text { Malic } \\
\text { acid }\end{array}$ & $\begin{array}{l}\text { Malonic } \\
\text { acid }\end{array}$ & $\begin{array}{l}\text { Oxalic } \\
\text { acid }\end{array}$ & $\begin{array}{l}\text { Propionic } \\
\text { acid }\end{array}$ & $\begin{array}{l}\text { Tartaric } \\
\text { acid }\end{array}$ \\
\hline \multirow{7}{*}{ So } & T0 & 22.93 a-f & $16.02 \mathrm{abc}$ & $20.53 \mathrm{a}-\mathrm{d}$ & 20.04 a-f & $14.59 \mathrm{a}-\mathrm{e}$ & 24.14 b-e & 20.65 a-d & $22.31 \mathrm{ab}$ & $14.06 \mathrm{a}-\mathrm{e}$ \\
\hline & T1 & 15.15 ef & $16.84 \mathrm{abc}$ & $15.40 \mathrm{bcd}$ & $13.78 \mathrm{def}$ & $10.15 \mathrm{~d}-1$ & $18.34 \mathrm{e}$ & $13.21 \mathrm{def}$ & $18.29 \mathrm{a}-\mathrm{d}$ & $9.70 \mathrm{de}$ \\
\hline & $\mathbf{T} 2$ & 20.99 a-f & $17.62 \mathrm{ab}$ & $17.24 \mathrm{bcd}$ & $16.67 \mathrm{c}-\mathrm{f}$ & $9.16 \mathrm{f}-1$ & $23.83 \mathrm{~b}-\mathrm{e}$ & 11.90 ef & $15.08 \mathrm{~b}-\mathrm{f}$ & $14.31 \mathrm{a}-\mathrm{e}$ \\
\hline & T3 & $28.96 \mathrm{a}$ & $16.41 \mathrm{abc}$ & $22.33 \mathrm{abc}$ & $23.58 \mathrm{abc}$ & $12.59 \mathrm{a}-\mathrm{g}$ & $30.95 \mathrm{ab}$ & $19.39 \mathrm{a}-\mathrm{f}$ & $18.95 \mathrm{abc}$ & $20.46 \mathrm{a}$ \\
\hline & T4 & $26.90 \mathrm{abc}$ & $16.77 \mathrm{abc}$ & $22.78 \mathrm{abc}$ & $20.04 \mathrm{a}-\mathrm{f}$ & $14.58 \mathrm{a}-\mathrm{e}$ & 25.60 a-e & $23.18 \mathrm{ab}$ & $22.66 \mathrm{ab}$ & $16.05 \mathrm{abc}$ \\
\hline & T5 & $25.21 \mathrm{a}-\mathrm{d}$ & $20.18 \mathrm{a}$ & $24.03 \mathrm{ab}$ & $27.28 \mathrm{a}$ & $15.79 \mathrm{ab}$ & $29.38 \mathrm{abc}$ & $23.05 \mathrm{ab}$ & $23.11 \mathrm{a}$ & $17.50 \mathrm{ab}$ \\
\hline & T6 & 22.35 a-f & $14.79 \mathrm{bc}$ & $19.85 \mathrm{bcd}$ & 21.93 a-e & $6.48 \mathrm{~h} 1$ & $18.12 \mathrm{e}$ & $15.69 \mathrm{~b}-\mathrm{f}$ & $8.02 \mathrm{f}$ & $13.62 \mathrm{~b}-\mathrm{e}$ \\
\hline \multirow{7}{*}{ S1 } & T0 & $19.14 \mathrm{c}-\mathrm{f}$ & $17.71 \mathrm{ab}$ & $17.37 \mathrm{bcd}$ & 19.65 a-f & $14.13 \mathrm{a}-\mathrm{f}$ & $22.22 \mathrm{cde}$ & $19.45 \mathrm{a}-\mathrm{e}$ & $21.80 \mathrm{ab}$ & $16.05 \mathrm{abc}$ \\
\hline & T1 & $17.25 \mathrm{def}$ & $17.10 \mathrm{abc}$ & $14.59 \mathrm{bcd}$ & $18.09 \mathrm{~b}-\mathrm{f}$ & $10.28 \mathrm{~d}-1$ & $18.64 \mathrm{e}$ & $15.10 \mathrm{c}-\mathrm{f}$ & $19.30 \mathrm{abc}$ & $10.39 \mathrm{cde}$ \\
\hline & $\mathbf{T 2}$ & $13.73 \mathrm{f}$ & $18.48 \mathrm{ab}$ & $14.05 \mathrm{~cd}$ & 13.18 ef & $9.71 \mathrm{e}-1$ & $19.48 \mathrm{de}$ & $10.94 \mathrm{f}$ & $14.19 \mathrm{c}-\mathrm{f}$ & $9.59 \mathrm{de}$ \\
\hline & T3 & $23.26 \mathrm{a}-\mathrm{e}$ & $18.78 \mathrm{ab}$ & $16.63 \mathrm{bcd}$ & $17.63 \mathrm{c}-\mathrm{f}$ & $9.25 \mathrm{f}-1$ & $25.88 \mathrm{a}-\mathrm{e}$ & $13.10 \mathrm{def}$ & 15.77 a-e & $13.76 \mathrm{~b}-\mathrm{e}$ \\
\hline & T4 & $21.01 \mathrm{a}-\mathrm{f}$ & $19.61 \mathrm{ab}$ & $19.71 \mathrm{bcd}$ & $22.53 \mathrm{a}-\mathrm{d}$ & 15.09 a-d & $22.26 \mathrm{cde}$ & $21.42 \mathrm{abc}$ & $23.34 \mathrm{a}$ & $17.42 \mathrm{ab}$ \\
\hline & T5 & $28.71 \mathrm{ab}$ & $17.62 \mathrm{ab}$ & $29.34 \mathrm{a}$ & $27.02 \mathrm{ab}$ & $17.21 \mathrm{a}$ & $33.36 \mathrm{a}$ & $21.78 \mathrm{abc}$ & $21.32 \mathrm{abc}$ & $18.26 \mathrm{ab}$ \\
\hline & T6 & $25.45 \mathrm{a}-\mathrm{d}$ & $16.56 \mathrm{abc}$ & $21.46 \mathrm{a}-\mathrm{d}$ & $23.17 \mathrm{abc}$ & 5.511 & $21.45 \mathrm{cde}$ & $16.96 \mathrm{a}-\mathrm{f}$ & 8.75 ef & $15.49 \mathrm{a}-\mathrm{d}$ \\
\hline \multirow{7}{*}{ S2 } & T0 & $19.46 \mathrm{~b}-\mathrm{f}$ & $17.50 \mathrm{abc}$ & $18.45 \mathrm{bcd}$ & $17.63 \mathrm{c}-\mathrm{f}$ & $11.80 \mathrm{~b}-\mathrm{g}$ & $18.61 \mathrm{e}$ & $17.96 \mathrm{a}-\mathrm{f}$ & $18.90 \mathrm{abc}$ & 14.66 a-e \\
\hline & T1 & 22.18 a-f & $18.44 \mathrm{ab}$ & $23.49 \mathrm{abc}$ & $25.11 \mathrm{abc}$ & $15.29 \mathrm{abc}$ & $31.58 \mathrm{ab}$ & 19.49 a-e & $21.01 \mathrm{abc}$ & $16.88 \mathrm{ab}$ \\
\hline & $\mathbf{T 2}$ & 14.23 ef & $18.05 \mathrm{ab}$ & $12.28 \mathrm{~d}$ & $12.83 \mathrm{f}$ & $8.40 \mathrm{gh}_{1}$ & $18.47 \mathrm{e}$ & $11.41 \mathrm{f}$ & 15.98 a-e & $8.84 \mathrm{e}$ \\
\hline & T3 & $18.92 \mathrm{c}-\mathrm{f}$ & $19.71 \mathrm{ab}$ & 20.40 a-d & $19.94 \mathrm{a}-\mathrm{f}$ & $9.30 \mathrm{f}-1$ & $20.97 \mathrm{cde}$ & $15.36 \mathrm{c}-\mathrm{f}$ & $11.13 \mathrm{def}$ & $16.86 \mathrm{ab}$ \\
\hline & T4 & $22.74 \mathrm{a}-\mathrm{f}$ & $14.77 \mathrm{bc}$ & $16.52 \mathrm{bcd}$ & 19.94 a-f & $10.71 \mathrm{c}-\mathrm{h}$ & $27.96 \mathrm{a}-\mathrm{d}$ & $16.96 \mathrm{a}-\mathrm{f}$ & $19.16 \mathrm{abc}$ & $16.23 \mathrm{abc}$ \\
\hline & T5 & 26.06 a-d & $17.29 \mathrm{abc}$ & $18.75 \mathrm{bcd}$ & $21.60 \mathrm{a}-\mathrm{f}$ & $11.83 \mathrm{~b}-\mathrm{g}$ & $23.62 \mathrm{~b}-\mathrm{e}$ & $24.10 \mathrm{a}$ & $19.82 \mathrm{abc}$ & $14.94 \mathrm{a}-\mathrm{e}$ \\
\hline & T6 & $28.09 \mathrm{abc}$ & $12.31 \mathrm{c}$ & $18.36 \mathrm{bcd}$ & $18.81 \mathrm{a}-\mathrm{f}$ & 5.571 & $19.95 \mathrm{de}$ & $13.70 \mathrm{def}$ & $9.63 \mathrm{ef}$ & $16.71 \mathrm{abc}$ \\
\hline
\end{tabular}

According to the Duncan Multiple Range Test, there is no statistical difference between the same letters given in the columns. $(\mathrm{p}<0.001)$

S0: $0 \mathrm{mM} \mathrm{NaCl}, \mathrm{S} 1: 150 \mathrm{mM} \mathrm{NaCl}, \mathrm{S} 2: 250 \mathrm{mM} \mathrm{NaCl}$, T0: no treatment (control), T1: $50 \mu \mathrm{M}$ hydrogen sulfide (H2S), T2: 50 $\mu \mathrm{M}$ Melatonin (ME), T3: $50 \mu \mathrm{M}$ Nitric oxide (NO), T4: $100 \mu \mathrm{M}$ H2S, T5: $100 \mu \mathrm{M}$ ME, T6: $100 \mu \mathrm{M}$ NO

\subsection{Root organic acid content}

We examined the potential roles of exogenous melatonin, hydrogen sulfide and nitric oxide in response to the root organic acid contents during salt stress. The results showed that salt stress considerably affected the root organic acids in comparison to the salt free plants. The content of butyric acid, fumaric acid, maleic acid, malonic acid, oxalic acid and propionic acid decreased, while citric acid level increased (Table 2). In contrast, application of all three amendments resulted in increased root organic acid contents either applied under salt stress or normal conditions. In the salt free environment, the highest root butyric acid, malonic acid and tartaric acid content were obtained at $50 \mu \mathrm{M}$ NO, the highest citric acid and propionic acid content at $100 \mu \mathrm{M} \mathrm{ME}$ and the highest fumaric acid and oxalic acid at $100 \mu \mathrm{M}$ HS and $100 \mu \mathrm{M}$ ME. Moreover, 
under $150 \mathrm{mM}$ salt stress, $100 \mu \mathrm{M}$ HS had the highest citric acid and propionic acid values, whereas $100 \mu \mathrm{M}$ NO was dominating in terms of the highest root butyric acid, fumaric acid, lactic acid, malonic acid and tartaric acid content. Likewise, $100 \mu \mathrm{M}$ ME efficiently increased maleic acid, oxalic acid and tartaric acid to their highest levels. Almost same pattern was followed under $250 \mathrm{mM}$ salt stress, where $100 \mu \mathrm{M}$ NO showed the highest values for most of the root organic acids, including butyric acid, fumaric acid, lactic acid, malonic acid and tartaric acid. When various treatments were compared, all exogenously applied amendments predominately increased the root organic acid contents; however, under salt stress conditions the effect of nitric oxide and melatonin was more obvious. Higher the application rate, the higher was the efficiency.

Table 2. The effects of exogenous treatments and salinity on organic acid contents of rocket roots (ng/ $\mu \mathrm{g})$

\begin{tabular}{|c|c|c|c|c|c|c|c|c|c|c|}
\hline Salt & Treatment & $\begin{array}{l}\text { Butyric } \\
\text { acid }\end{array}$ & $\begin{array}{l}\text { Citric } \\
\text { acid }\end{array}$ & $\begin{array}{l}\text { Fumaric } \\
\text { acid }\end{array}$ & $\begin{array}{l}\text { Lactic } \\
\text { acid }\end{array}$ & $\begin{array}{l}\text { Maleic } \\
\text { acid }\end{array}$ & $\begin{array}{l}\text { Malonic } \\
\text { acid }\end{array}$ & $\begin{array}{l}\text { Oxalic } \\
\text { acid }\end{array}$ & $\begin{array}{l}\text { Propionic } \\
\text { acid }\end{array}$ & $\begin{array}{l}\text { Tartaric } \\
\text { acid }\end{array}$ \\
\hline \multirow{7}{*}{ So } & T0 & $0.16 \mathrm{c}-\mathrm{f}$ & $0.22 \mathrm{abc}$ & 0.12 cde & $0.11 \mathrm{c}-\mathrm{g}$ & $013 \mathrm{a}$ & $0, .1 \mathrm{~b}-\mathrm{e}$ & $0.16 \mathrm{a}-\mathrm{d}$ & $0.23 \mathrm{ab}$ & $0.05 \mathrm{bc}$ \\
\hline & T1 & $0.11 \mathrm{f}$ & $0.23 \mathrm{abc}$ & $0.09 \mathrm{de}$ & $0.08 \mathrm{f}$ & $0.07 \mathrm{bcd}$ & $0.08 \mathrm{de}$ & $0.10 \mathrm{def}$ & $0.19 \mathrm{abc}$ & $0.03 \mathrm{c}$ \\
\hline & $\mathbf{T 2}$ & $0.15 \mathrm{c}-\mathrm{f}$ & $0.24 \mathrm{ab}$ & $0.10 \mathrm{de}$ & $0.09 \mathrm{efg}$ & $0.05 \mathrm{~cd}$ & $0.10 \mathrm{~b}-\mathrm{e}$ & 0.09 ef & $0.15 \mathrm{~b}-\mathrm{g}$ & $0.05 b c$ \\
\hline & T3 & $0.20 \mathrm{bc}$ & $0.23 \mathrm{abc}$ & $0.13 \mathrm{bcd}$ & $0.13 \mathrm{cde}$ & $0.06 \mathrm{~cd}$ & $0.14 \mathrm{bc}$ & $0.14 \mathrm{a}-\mathrm{f}$ & $0.19 \mathrm{abc}$ & $0.07 \mathrm{~b}$ \\
\hline & T4 & 0.19 cde & $0.23 \mathrm{abc}$ & $0.14 \mathrm{bcd}$ & $0.11 \mathrm{c}-\mathrm{g}$ & $0.13 \mathrm{a}$ & $0.11 \mathrm{~b}-\mathrm{e}$ & $0.18 \mathrm{ab}$ & $0.23 \mathrm{ab}$ & $0.05 \mathrm{bc}$ \\
\hline & T5 & 0.18 cde & $0.28 \mathrm{a}$ & $0.14 \mathrm{bcd}$ & $0.15 \mathrm{bc}$ & $0.06 \mathrm{~cd}$ & $0.13 \mathrm{bcd}$ & $0.18 \mathrm{ab}$ & $0.24 \mathrm{a}$ & $0.06 \mathrm{bc}$ \\
\hline & T6 & $0.16 \mathrm{c}-\mathrm{f}$ & $0.20 \mathrm{bc}$ & 0.12 cde & $0.12 \mathrm{c}-\mathrm{g}$ & $0.03 \mathrm{~cd}$ & $0.08 \mathrm{de}$ & 0.12 & $0.08 \mathrm{~g}$ & $0.04 \mathrm{bc}$ \\
\hline \multirow{7}{*}{ S1 } & T0 & $0.13 \mathrm{c}-\mathrm{f}$ & $0.24 \mathrm{ab}$ & $0.10 \mathrm{de}$ & $0.11 \mathrm{c}-\mathrm{g}$ & 0.08 a-d & $0.10 \mathrm{~b}-\mathrm{e}$ & 0.15 a-e & $0.22 \mathrm{ab}$ & $0.05 \mathrm{bc}$ \\
\hline & T1 & 0.12 ef & $0.23 \mathrm{abc}$ & $0.09 \mathrm{de}$ & $0.10 \mathrm{c}-\mathrm{g}$ & $0.06 \mathrm{~cd}$ & $0.08 \mathrm{de}$ & 0.12 b-f & $0.20 \mathrm{abc}$ & $0.03 \mathrm{c}$ \\
\hline & T2 & $0.10 \mathrm{f}$ & $0.25 \mathrm{ab}$ & $0.08 \mathrm{de}$ & $0.07 \mathrm{~g}$ & $0.07 \mathrm{a}-\mathrm{d}$ & 0.09 cde & $0.08 \mathrm{f}$ & $0.14 \mathrm{c}-\mathrm{g}$ & $0.03 \mathrm{c}$ \\
\hline & T3 & $0.16 \mathrm{c}-\mathrm{f}$ & $0.26 \mathrm{ab}$ & $0.10 \mathrm{de}$ & $0.10 \mathrm{c}-\mathrm{g}$ & $0.05 \mathrm{~cd}$ & 0.09 cde & $0.10 \mathrm{def}$ & 0.16 a-e & $0.04 \mathrm{bc}$ \\
\hline & T4 & $0.15 \mathrm{c}-\mathrm{f}$ & $0.27 \mathrm{ab}$ & 0.12 cde & $0.13 \mathrm{cde}$ & $0.07 \mathrm{a}-\mathrm{d}$ & $0.10 \mathrm{~b}-\mathrm{e}$ & $0.17 \mathrm{abc}$ & $0.24 \mathrm{a}$ & $0.06 \mathrm{bc}$ \\
\hline & T5 & $0.20 \mathrm{bc}$ & $0.24 \mathrm{ab}$ & $0.17 \mathrm{abc}$ & $0.15 b c$ & $0.09 \mathrm{abc}$ & $0.15 \mathrm{~b}$ & $0.17 \mathrm{abc}$ & $0.22 \mathrm{ab}$ & $0.06 \mathrm{bc}$ \\
\hline & T6 & $0.25 \mathrm{ab}$ & $0.17 \mathrm{~cd}$ & $0.21 \mathrm{a}$ & $0.23 \mathrm{a}$ & $0.03 \mathrm{~cd}$ & $0.21 \mathrm{a}$ & $0.17 \mathrm{abc}$ & $0.09 \mathrm{fg}$ & $0.15 \mathrm{a}$ \\
\hline \multirow{7}{*}{$\mathbf{S 2}$} & T0 & $0.14 \mathrm{c}-\mathrm{f}$ & $0.24 \mathrm{ab}$ & $0.11 \mathrm{de}$ & $0.10 \mathrm{c}-\mathrm{g}$ & $0.09 \mathrm{abc}$ & $0.08 \mathrm{de}$ & 0.14 a-f & $0.19 \mathrm{abc}$ & $0.05 \mathrm{bc}$ \\
\hline & T1 & $0.16 \mathrm{c}-\mathrm{f}$ & $0.25 \mathrm{ab}$ & $0.14 \mathrm{bcd}$ & $0.14 \mathrm{~b}-\mathrm{e}$ & $0.06 \mathrm{~cd}$ & $0.14 \mathrm{bc}$ & $0.15 \mathrm{a}-\mathrm{e}$ & $0.21 \mathrm{abc}$ & $0.06 \mathrm{bc}$ \\
\hline & $\mathbf{T 2}$ & $0.10 \mathrm{f}$ & $0.25 \mathrm{ab}$ & $0.07 \mathrm{e}$ & $0.07 \mathrm{~g}$ & $0.07 \mathrm{a}-\mathrm{d}$ & $0.08 \mathrm{de}$ & 0.09 ef & 0.16 a-e & $0.03 \mathrm{c}$ \\
\hline & T3 & $0.13 \mathrm{c}-\mathrm{f}$ & $0.27 \mathrm{ab}$ & $0.12 \mathrm{cde}$ & $0.11 \mathrm{c}-\mathrm{g}$ & $0.03 \mathrm{~cd}$ & $0.08 \mathrm{de}$ & $0.12 \mathrm{~b}-\mathrm{f}$ & $0.11 \mathrm{~d}-\mathrm{g}$ & $0.06 \mathrm{bc}$ \\
\hline & T4 & $0.16 \mathrm{c}-\mathrm{f}$ & $0.20 \mathrm{bc}$ & $0.10 \mathrm{de}$ & $0.11 \mathrm{c}-\mathrm{g}$ & 0.08 a-d & $0.12 \mathrm{~b}-\mathrm{e}$ & $0.13 \mathrm{a}-\mathrm{f}$ & 0.19 abc & $0.05 \mathrm{bc}$ \\
\hline & T5 & $0.18 \mathrm{cde}$ & $0.24 \mathrm{ab}$ & $0.11 \mathrm{de}$ & $0.12 \mathrm{c}-\mathrm{g}$ & $0.14 \mathrm{a}$ & $0.10 \mathrm{~b}-\mathrm{e}$ & $0.19 \mathrm{a}$ & $0.20 \mathrm{abc}$ & $0.05 \mathrm{bc}$ \\
\hline & T6 & $0.28 \mathrm{a}$ & $0.12 \mathrm{~d}$ & $0.18 \mathrm{ab}$ & $0.19 \mathrm{ab}$ & $0.02 \mathrm{~d}$ & $0.20 \mathrm{a}$ & 0.14 a-f & 0.10 efg & $0.17 \mathrm{a}$ \\
\hline
\end{tabular}

According to the Duncan Multiple Range Test, there is no statistical difference between the same letters given in the columns. $(\mathrm{p}<0.001)$

S0: $0 \mathrm{mM} \mathrm{NaCl}, \mathrm{S} 1: 150 \mathrm{mM} \mathrm{NaCl}, \mathrm{S} 2: 250 \mathrm{mM} \mathrm{NaCl}$, T0: no treatment (control), T1: $50 \mu \mathrm{M}$ hydrogen sulfide (H2S), T2: 50 $\mu \mathrm{M}$ Melatonin (ME), T3: $50 \mu \mathrm{M}$ Nitric oxide (NO), T4: $100 \mu \mathrm{M}$ H2S, T5: $100 \mu \mathrm{M}$ ME, T6: $100 \mu \mathrm{M}$ NO

Salinity is one of the most important environmental variables that can limit plant growth and development, as well as create a variety of physiological, anatomical, and morphological impacts [8]. Organic acids are found in all plants and have important roles in plant physiology. The amount and type of organic acids may differ according to the type, plant species, plant tissue and developmental stage [9]. The organic acid metabolism in plant plays a key role for tolerance to salinity [10]. In our study, the reaction to salt stress occurred with the changes in the organic acid metabolism in plant leaves and roots. In a previous study, it was stated that salt stress significantly reduced the organic acid content in alfalfa nodules [11]. However, with the exogenous applications used in the study, increase or decrease occurred according to the organic acid type, and these substances were included in the plant salt tolerance effects. The results of our study showed an increase in the organic acid contents of the examined plant parts with the exogenous application of melatonin. Our results are in accordance with the study conducted by Samanta et al. [12], where melatonin efficiently restored the levels of various organic acids under arsenic stress. Similarly, Zhang et al. [13] found that supplementing soybeans with $1 \mu \mathrm{M}$ M Melatonin boosted malate and citrate exudation during aluminum (Al) stress. In another study, Shi et al. [14] concluded that exogenously melatonin treated Bermuda grass plants exhibited higher concentrations of 54 metabolites, including organic acids and amino 
acids under abiotic stress. An improvement in the content of various organic acids upon the exogenous application of melatonin to the tomato fruit under stress conditions was reported [15].

The findings of our study also confirmed the beneficial effects of hydrogen sulfide and nitric oxide under salinity stress. These results are confirmed by the findings of Vital et al. [16] according to them nitric oxide regulated the organic acid and amino acids of soybean plants under high temperature.

In a study conducted by Shi et al. [17] hydrogen sulfide application was found to regulate 50 carbon metabolites, including organic acids, amino acids, aromatic amines, sugars and sugar alcohols under biotic and abiotic stresses.

The metabolic regulation effect of organic acids in salty conditions may be due to the fact that they contain enzymes that participate in some metabolic pathways [18]. The changes observed in organic acid synthesis with the amendments used in the study may be due to the regulation of enzyme activities in plant metabolism by these substances.

\section{Conclusion}

The effect of exogenously applied melatonin, hydrogen sulfide and nitric oxide on plant organic acid contents under salt stress was investigated. The results demonstrated that salt stress led to a considerable decrease in the levels of various organic acids at both salt levels. The organic acid contents, which showed a decline trend with salt stress, varied with these exogenous applications and generally showed an increasing pattern. All the amendments were significant in ameliorating the salt stress on the organic acid metabolism in saline environment; however, a variation was noted among the studied plant parts. In leaves, for example the effect was more obvious for $50 \mu \mathrm{M}$ hydrogen sulfide under $250 \mathrm{mM} \mathrm{NaCl}$ stress, while $100 \mu \mathrm{M} \mathrm{ME} \mathrm{had}$ the best results under $150 \mathrm{mM} \mathrm{NaCl}$ stress. In terms of roots, conversely, nitric oxide at its highest rate (100 $\mu \mathrm{M}$ NO) illustrated the highest values for most of the organic acids.

The finding of our study supports the use of exogenous application of these molecules in ameliorating the salinity stress of plants with their role in plant organic acid metabolism.

\section{References}

1. J.K. Zhu, "Salt and drought stress signal transduction in plants", Annual Review of Plant Biology, 53, pp. $247-273.2002$.

2. Z. Jouyban, "The effects of salt stress on plant growth", Engineering Applied Sciences, 2(1), pp. 7-10. 2012.

3. V. Martinez, J.M. Nuñez, A. Ortiz, A. Cerda, "Changes in amino acid and organic acid composition in tomato and cucumber plants in relation to salinity and nitrogen nutrition". Journal Plant Nutrition, 17(8), pp. 1359-1368. 1994.

4. J. Li, J. Liu, T. Zhu, C. Zhao, L. Li, M. Chen, "The role of melatonin in salt stress responses”, International Journal Molecular Sciences, 20(7), pp. 1735. 2019.

5. M. Hasanuzzaman, H. Oku, K. Nahar, M.B. Bhuyan, J. Al Mahmud, F. Baluska, M. Fujita, "Nitric oxide-induced salt stress tolerance in plants: ROS metabolism, signaling, and molecular interactions", Plant Biotechnology Reports, 12(2), pp. 77-92, 2018.

6. Z.G. Li, X. Min, Z.H. Zhou, "Hydrogen sulfide: a signal molecule in plant cross-adaptation”, Frontiers in Plant Science, 7, pp. 1621, 2016.

7. S.N. Siddiqui, S. Umar, M. Iqbal, "Zinc-induced modulation of some biochemical parameters in a high- and a low-zinc-accumulating genotype of Cicerarietinum L. grown under Zn-deficient condition", Protoplasma, 252, 1335-1345, 2015.

8. Liu J, Wang W, Wang L, Sun Y. 2015. Exogenous melatonin improves seedling health index and drought tolerance in tomato. Plant Growth Regulation 77, pp. 317-326. 2015.

9. Vallarino, J. G., Osorio, S., 2019. Organic acids. In Postharvest physiology and biochemistry of fruits and vegetables (pp. 207-224). Woodhead Publishing.

10. M. Sheng, M. Tang, F. Zhang, Y. Huang, "Influence of arbuscular mycorrhiza on organic solutes in maize leaves under salt stress", Mycorrhiza, pp. 21, 423-430, 2011 
11. F. Fougere, D. Le Rudulier, J.G, Streeter, "Effects of salt stress on amino acid, organic acid, and carbohydrate composition of roots, bacteroids, and cytosol of alfalfa (Medicago sativa L.)". Plant Physiology, 96(4), pp. 1228-1236, 1991

12. S. Samanta, A. Singh, A. Banerjee, A. Roychoudhury, "Exogenous supplementation of melatonin alters representative organic acids and enzymes of respiratory cycle as well as sugar metabolism during arsenic stress in two contrasting indica rice cultivars", Journal of Biotechnology, 20(324), pp. 220-232, 2020.

13. J. Zhang, B. Zeng, Y. Mao, X. Kong, X. Wang, Y. Yang, J. Zhang, J. Xu, Z. Rengel, Q. Chen, "Melatonin alleviates aluminium toxicity through modulating anti oxidative enzymes and enhancing organic acid anion exudation in soybean”, Functional Plant Biology, 44(10), pp. 961-968, 2017.

14. H. Shi, C. Jiang, T. Ye, D.X. Tan, R.J. Reiter, H. Zhang, "Comparative physiological, metabolomic, and transcriptomic analyses reveal mechanisms of improved abiotic stress resistance in bermudagrass [Cynodon dactylon (L) by exogenous melatonin”, Experimental Botany, 66(3), pp. 681-694, $2015 \mathrm{a}$.

15. J. Liu, R. Zhang, Y. Sun, Z. Liu, W. Jin, Y. Sun, "The beneficial effects of exogenous melatonin on tomato fruit properties", Scientia Horticulturae, 207, pp. 14-20, 2016.

16. R.G Vital, C. Müller, F.B. da Silva, P.F. Batista, A. Merchant, D. Fuentes, A.A. Rodrigues, A.C. Costa, "Nitric Oxide Increases the Physiological and Biochemical Stability of Soybean Plants under High Temperature", 2019

17. H. Shi, T. Ye, N. Han, H. Bian, X. Liu, Z. Chan, "Hydrogen sulfide regulates abiotic stress tolerance and biotic stress resistance in Arabidopsis", Integrative Plant Biology, 57(17), pp. 628-640, 2014. 